九州大学学術情報リポジトリ

Kyushu University Institutional Repository

\title{
Structures for Organization of Transactions in Bulgarian Agriculture
}

Bachev, Hrabrin

Institute of Agricultural Econoimcs, Sofia, Bulgaria

Tsuji, Masao

Laboratory of Farm Management, Division of Ineternational Agricultural Resource Economics and Business Administration, Department of Agricultural and Resource Economics, Faculty of Agriculture, Kyushu University

https://doi.org/10.5109/24429

出版情報: 九州大学大学院農学研究院紀要. 46 (1)，pp.123-151，2001-10-30. Kyushu University バージョン：

権利関係 : 


\title{
Structures for Organization of Transactions in Bulgarian Agriculture
}

\author{
Hrabrin BACHEV* and Masao TSUJI
}

Laboratory of Farm Management, Division of International Agricultural Resource Economics and Business Administration, Department of Agricultural and Resource Economics, Faculty of Agriculture, Kyushu University, Fukuoka 812-8581, Japan

(Received April 17, 2001 and accepted July 11, 2001)

In this paper we extend our previous efforts to incorporate achievements of the New Institutional and Transaction Cost Economics to the agrarian sphere. First, we demonstrate that Bulgarian agrarian economy is a Transaction cost economy, and clarify various types of transacting costs in transitional conditions. Next, we describe existing structures for governing of agrarian transactions, and evaluate their costs minimizing and incentive potential. Lastly, we estimate prospects for organizational modernization, and determine effective boundaries of market, private, public, and mixed modes for agrarian transacting.

Neoclassical scenario for transformation of previous communist model ("free market plus private ownership") has not worked in Bulgarian agriculture. Transition has changed "rules of the game" but it has not made agrarian agents "more rational" and "less opportunistic". Consequently costs for new property rights and institutional development, and for market and private modes of individual transacting, have taken a good part of all social expenditures. High assets dependency, big uncertainty, low appropriability, and less frequency have determined a specific transitional structure of agrarian transacting. Less market transacting, big reliance on informal relationships at large scale, great extent of "over" integrated modes, part time farming and production cooperation phenomenon, block of all classes of transactions etc, all have come to existence. Besides, a large number of inefficient or contradictory third party (e.g. Government, Non-governmental organizations, international assistance etc) involvements in agrarian transacting have been in place. All this has deformed substantially emerging farming system, and domination of primitive and "gray" structures, little sustainability of large business and cooperative farms, significant distortion of national agrarian capital, and backward technological "development", have come to agenda.

Low efficiency of public in-house organization and limited budget sources would restrict Government direct intervention in agrarian transactions. Agrarian policy should be toward exploring potential of market, private, and cooperative modes through new property rights provision, institutional and infrastructural support, improving law and contract enforcement, market information, extension education, assisting farmers association etc. Less expensive modes for trilateral governance (coordination, control on opportunism, incentives for specific investments) with active involvement of private sector and farmers organizations are to be preferred.

\section{INTRODUCTION}

There has been an unprecedented transformation of Bulgarian agriculture since 1989 when a transition from Communist to a market economy started. Institutional modern-

\footnotetext{
* Senior Researcher, Institute of Agricultural Economics, Sofia, Bulgaria.

This study has been made in Kyushu University with a financial support from the Japan Foundation (1999-2000)
} 
ization has been driven both by socio-economic reforms of Governments and various "collective efforts" of individuals. Process of transition toward a modern farming has been much more expensive and slower than expected. Moreover, outcomes of undertaken policies have often been quite different than initially designed. To a great extent that has been a result of domination of Neoclassical ("cost free") assumptions for institutional development according to which "imported" western institutions would "work" efficiently in local conditions. Official ignorance of transaction costs and factors for their minimization has led to formation of specific transitional structures with a big variety of formal and informal modes of transacting. Besides, traditional framework continues to be used by mainstream "transitional economists" despite enormous theoretical and "practical" development (Coase, Furuboth and Richter, North, Williamson). However, "transaction free" approach has been able neither to explain much of phenomenon in transitional agriculture nor to be used in effective institutional design.

In this paper we extend our previous efforts to incorporate achievements of the New Institutional and Transaction Cost Economics to the agrarian sphere (Bachev and Tsuji 2001). We argue that implementation of this concept to transitional Bulgarian agriculture would allow us: to reexamine driving factors for institutional and organizational development; to determine potential of different market, private, and hybrid forms of transacting; and ultimately to put reform policy and (agro) business strategy formation on more realistic fundaments. First, we try to demonstrate that Bulgarian agrarian economy is a Transaction cost economy, and clarify various types of transacting costs in transitional conditions. Next, we describe existing structures for governing of agrarian transactions, and evaluate their costs minimizing and incentive potential. Lastly, we estimate prospects for organizational modernization, and determine effective boundaries of market, private, public, and mixed modes for agrarian transacting.

\section{TRANSACTION COST ECONOMICS OF TRANSITIONAL AGRARIAN ECONOMY}

\section{Collapse of the previous model}

During the Communist period there was an extremely inefficient system for governing of agriculture (Bachev p. 181). Individuals had no freedom to use market and private modes for organization of their transactions. "Coordination and motivation" of major agrarian activities were carried through a mandatory central plan ${ }^{i}$. It was associated with enormous costs for "development of plan"; "control, stimulation, and reporting"; "correction of disbalance and current adaptation"; overcoming "private use" of public resources (stealing working time and other assets) etc. It required a complex hierarchical organization with overcrowded staff at farm, local, regional and national levels (reaching up to one bureaucrat for one directly engaged in farming) ${ }^{2}$. Besides,

\footnotetext{
${ }^{1}$ Production units got detailed directives ("mandatory indicators") about: land distribution, production and technological structures, staff and workers numbers, expenditures levels and structure, income distribution etc. In last years so called "upward planning" was introduced (as a supplement to "downward planing") in order to increase basic units involvement in development of the National plan ("provide information" about potential of available resources and technologies, "create incentives" for individual contribution etc).
} 
there were no objective criteria for evaluation of economic performance ("judgement of market") ${ }^{3}$. That was giving a great opportunity for "central using" of public resources (instead for overall "social efficiency") in best interests of a particular person (s) or social groups (nomenclature, "security sectors").

Agrarian agents were supposed to be "fully rational" and their interests "in line with public interests". Instead of this harmony in organization of agrarian transacting "partial" crisis followed year after year ("over" or "under" production, "quality failures", innovation "problems", management "shortcomings" etc). "Permanent reorganization" and various "economic mechanisms" were unsuccessfully experimented to "fix the system". Personal farming (plots) and "market like" management ("partial autonomy" and "self-management" of main production units, "residual formation of incomes" in public farms, "free" farmers markets) were introduced to fill the gap. Various forms of "unwanted" exchanges were used to secure plan implementation ("personal orders" for members of Communist party and associated organizations; use of nonfarmer labors, students, and military for farming activities, etc). Besides, "informal" modes were broadly applied as a substitute for inefficient official system of management (interlinked transacting, "personal relations", "waiting system", "free" use of public resources for private consumption or activities).

All these eventually led to a collapse of existing "public farming" model. Since 1989 a fundamental transformation toward a market oriented and private based agriculture has been in place. Economic activity has been liberalized, farmland and other agrarian assets have been restituted or privatized, and a policy for institutional and legislative approximation with the European Union has been undertaken (Bachev p. 184). Post communist agrarian transition has been associated with significant changes in type of transactions and structure of transacting costs.

\section{Long term transaction costs for institutional modernization}

Long-term costs for property rights and institutional modernization have taken a substantial part of overall transaction costs in agrarian area.

Firstly, there have been great transaction costs for development and implementation of agrarian transformation policy ("institutional environment"). All major aspects of agrarian reform (market liberalization; introduction of new agrarian property and contracting rights; restitution; privatization and reorganization of public companies, etc) have been subjects of heated public debates (about character, pace, extend of process etc). Besides, development of formal institutions (legislation and regulations, specialized agencies for implementation and enforcement) has not been without controversies. All basic Laws for agrarian transformation have got a lot of "improvement" and amendments some of which quite fundamental ${ }^{4}$. These affected significantly overall social costs (in

\footnotetext{
${ }^{2}$ Moreover, there was a symmetrical Communist Party structures at all levels (for governing and control) to secure success of plan implementation.

${ }^{3}$ Managers and workers were evaluated (and part of their salaries depended) according to "achievement and overachivement of plan indicators". That is why there were strong incentives to get low mandatory plan from Center (hiding or misleading real production potential) in order to show "higher progress in the end of plan period", or (more commonly) to avoid intensification of efforts for official plan implementation (and saving time for private transactions).
} 
term of time, tax-payers money, individual costs for political and economic transactions) for building of new institutional framework of agrarian sphere.

Secondly, there have been enormous costs for carrying out restitution, distribution, and privatization of agrarian resources (costs associated with activities of different responsible bodies, for preparing various regulations for their activities, and for public enforcement etc).

Identification of "eligible shareholders" and actual distribution of the assets of previous cooperatives into individual shares have taken almost four years. It has been connected with large direct costs for personalization (specification, evaluation, dispute resolution, transfer) of ownership on various assets and it is still incompleted for some disputed property. Also there have been substantial indirect costs associated with activities of Liquidation Councils-mismanagement of production process, physical distortion of a great part of assets (buildings, irrigation systems, fruit trees and vineyards, livestock), inefficient deals and corruption, unfair allocation of property, etc. In some cases overall costs for transfer of ownership to private hands have reached more than one fifth of the value of cooperative assets.

Restoration of private rights on farmland land has been a very costly and lengthy process. It started in 1991 and it is still going on for a part of claimed area ${ }^{5}$. It has taken a lot of social resources (public, individual, international assistance) for identification of previous owmers, resolution of conflicts between claimants, development of land division plans, issuing of various ownership certificates and final notaries acts, for actual introduction into land use and ownership ("temporarily", "preliminary", "in real borders") etc. Besides, permanent transfer of state and municipality owned farmand into private management is still to be accomplished ${ }^{6}$. Little competence and widespread corruption of Land Commissions have contributed to high "social price" for privatization of agricultural land. Moreover, significant losses have been realized as a consequence of slow restoration of real ownership titles (lack of incentives for long term investments in land, decrease in efficiency of land use) $)^{7}$.

Privatization of the assets of state farms and agrocompanies has been very slow ${ }^{8}$. It

\footnotetext{
"For instance, initially restitution of farmland could have been in "ideal borders"; later on an introduction into ownership in real (old or new comparable) borders has been ruled out. "Distribution of property" of former cooperatives into individual shares has been replaced by liquidation of existing production structures (and physical distribution of assets between individuals). Besides, various amendments have put quite different restrictions on land ownership (size, eligibility for foreigners) and lease (size and period), and a number of assets forms (cash, mass, combine, zunk or compensatory payments, managerial-workers) have been introduced for privatization of state and municipality (Bachev at all, 2000).

${ }^{5} \mathrm{By}$ the end of 2000 restitution of rights on about $98 \%$ of claimed farmland was entirely completed.

${ }^{6}$ It accounts $19 \%$ of total farmland in the country (4.8\% of arable land, and $71.8 \%$ of grassland and pastures)

Prereform yield levels for major cereals, fruit, and vegetables have dropped by up to $40 \%$, and uncultivated area got up to one forth of total arable land. Besides, there have been rising crop rotation problems in some regions.

${ }^{8} \mathrm{By}$ the end of 2000 it accounts only for less than $50 \%$ of total assets in the system of Ministry for Agriculture, as share of completed deals were more than a half of number of opened privatization procedures.
} 
has been associated with high level of direct costs for identification and separation of state property, and for organization of privatization deals (preparation of offers, registration, carrying out tenders and sells). Also significant entrepreneurial efforts have been made for studying investment opportunities, for formation of various buyers ventures (groups, managerial-workers teams, legal entities), for accumulation of needed cash or individual privatization bonds etc. Besides, a large "informal costs" have been involved for various "transfer payments" for bribing corrupted members of Privatization Boards and responsible public officials. Lastly, big public losses have been made as a result of inefficient management (monopoly or quasi-monopoly situations, mismanagement), and "hidden" (or illegal) income and property transfer to private hands.

\section{Transaction costs for market and private modes}

Economic reform has turned every agrarian agent in an autonomous manager of his transactions. Number of active participants in various type of agrarian transacting (labor and inputs supply, marketing etc) has enlarged thousands folds. Intensity of market and private transacting has increased enormously as almost one forth of working population, about 1.8 millions new land owners, and arround 2.5 millions shareholders in accumulated agrarian assets ${ }^{9}$, participate in the process. Individual agents have been involved in all types of agrarian transactions (from capital supply to international trade) and exchange of new kinds of private rights (on land, labor, intellectual products etc). Now a great part of agrarian transacting is governed by market and private modes, and almost entire agrarian production is carried out by new developed private forms (farms, cooperatives, and agrofirms).

Individual transacting costs in fast changing institutional (new "rules of the game", unstable legislation and regulation framework) and macroeconomic (high inflation and transacting uncertainty) environment have been very high. Costs for market transactions have risen significantly during markets liberalization and transitional adjustment. Little personal experience in risk taking, marketing, contracting, private forms, has contributed to enlargement of transacting costs. Searching costs for finding best prices, markets, and partners; expenditures for market commissions, fees, and licenses; costs for negotiation and for contract writing; costs for safeguarding against partners opportunism (cheating, noncompliance); contract enforcement and dispute resolution costs (through private or court system), all have taken a good part of overall transacting costs. Besides, individual costs for protecting private absolute and contracted rights from unwanted exchange (opportunism, thieves, monopoly, "insurance payments" for criminal security firms etc) have risen substantially in absence of an effective public enforcement system.

Development costs for various market and private organizations (for initiating, design, formal registration, formation, restructuring, liquidation) have occupied a good part of all transaction costs in agrarian sphere. Large number of special governing modes for individual transacting has come to existence (collecting and wholesale markets, long-term contracts, cooperative agreements, associations for price negotiation, different

\footnotetext{
${ }^{9}$ All owners of farmland and workers (with at least 5 years stage) in previous cooperatives have been eligible to get shares in accumulated cooperative assets. Besides, every Bulgarian citizen older than 18 could take part in "mass privatization" of designated state agrarian assets.
} 
type of legal entities). After 1991 more than 1.7 million new private farms appeared; about 3200 new producers cooperatives have been formed with more than 770 thousand members; and 9800 different other agricultural organizations have been registered. Besides, a big number of informal partnerships, joint venture, strategic agreements as well as illegal ventures ("gray" and "black" economy) have been developed. Consequently costs for various forms of private management (decision making, coordination, evaluation, stimulation, and control) of transactions though contract modes, direct internal or joint management, group decision making, or in a hierarchy, have increased substantially.

\section{Costs for a third part involvement in agrarian transactions}

In new developing transacting environment (price adjustments, "missing" markets, unrestructured monopolies) there have been significant costs for a third party involvement in individual transactions. There have been large costs for public (state or local authorities), international agencies, and various nongovernmental organizations participation in agrarian transactions. There have been various forms for a third party involvement in market and private transacting such as: assistance (e.g. providing agromarket information, training in farm management, initiating farmers associations), regulations (e.g. setting price levels; standards for product quality, labor use, and environment protection; requirements for quality and origin certificates), public organization (e.g. extension service, sanitary and veterinary control), and hybrid modes (e.g. formation of wholesale market system, public subsidies to agrarian credit). In some cases public and individual costs for such trilateral forms of transacting have reached very high levels (for funding of special agencies, international loans repayments, mismanagement of programs, fighting against offenders, bribing responsible officials, participation fees and expenses, avoiding tax and other mandatory payments).

Also different special interests groups have made a lot of investments in "collective actions" (lobbying, bribing) to induce Government interventions in agrarian transactions in their interests (trade preferences, price regulations, redistribution of property rights). Not rare as a result of such successful actions some private groups have got "institutionalized" large benefits (rent) at the expense of other participants in transactions or general taxpayers ${ }^{10}$.

\section{GOVERNANCE MODES FOR AGRARIAN TRANSACTING}

\section{"Temporal" public modes of management}

For a long time a large part of agrarian transactions have been carry out in "temporal" governing structures-unrestructured former structures, and special organizations set up by authority (responsible for restitution, distribution, privatization or liquidation of agrarian resources).

Public (state, municipality, mixed) farms and agrofirms continue to be in place even nowadays (in irrigation, mechanization and other services, farming and related activities). Most of them have been "restructured" or got an autonomy status. However,

\footnotetext{
${ }^{10}$ To name just a few: fixed minimum prices for tobacco and wheat producers, preferential (subsidised) credit programs (working capital for cereal producers; long term investments for grain, livestock, grape, and some fruit producers).
} 
a little actually have changed in their "internal" management. Neither managers nor working teams have any incentives in long term efficiency (unclear future of organizations; restrictions on trade with long-term assets; regulation of salaries; losing "income rights" in case of retirement, sacking or restructuring). Ceasing "control from above" have made mismanagement and private use of public assets widespread (income transfers and property use, current on-job consumption etc). In many cases financial freedom has led to strengthening monopoly position of some companies (uncontrolled price increase, unilateral dependency of using farmers etc).

For a long period of time a significant portion of land supply transactions has been managed by (with a mediation of) special state authorities (Ministry of Agriculture, Land Commissions, Municipalities). Previous landowners have got recognized their rights but only less than one forth of them got real titles (notary acts) until the middle of $1999 "$ ". Allocation of all valuable agricultural land (for "temporal" one season use, "preliminary introduction into ownership") has been under control of Municipality Land Commissions. Often these Commissions have been used to "direct" new private farming development through Ministry regulations (or unwritten orders) for favorable policy toward "individual self-sufficient", "large scale business type", or "collective" organization of land supply (depending on the "current policy" of consecutive Government ${ }^{12}$ ). Lease contracts for state and municipality lands have been handled by Ministry of Agriculture (long-term contracts), regional Ministry Departments (one season contracts), and Municipalities. Interests of members of "land allocation" authorities have been away from efficient land organization, and there has been no system for an effective public control over their activities. Land supply organization substantially has affected formation of sustainable private structures and efficiency of land use. It also has been associated with a lot of irregularities, mismanagement, and high additional costs for land supply (bribes to get good land plots, continuing unresolved disputes etc). Besides, a significant part of "fixed" nonland agrarian assets has been abundant or destroyed (e.g. irrigation facilities, orchards, building), and a large area of productive land has been left unused for a long period of time.

Large part of agrarian transactions has been governed by various Liquidation Councils, and Privatization Boards, etc. Besides, for transformation of property (distribution into individual shares, privatization, liquidation of assets) these bodies have been responsible for "current" management of production activities in respective organizations ${ }^{13}$. For a very long period of time governance of a significant part of agrarian assets has been locked in these "dual function" organizations. There has been impossible an effective control on the performance of such temporal structures by numerous individual (eligible) shareholders, enforcing public agencies, or media (high uncertainty, asymmetry of information, and competency; "uniqueness" in every case; "mass" character of process etc). That is why organization of agrarian transactions has rarely been carried

\footnotetext{
"Mainly in low productive mountainous areas where restoration of land ownership was possible in "existing old borders".

${ }^{12}$ Between 1990 and 1997 there were 8 different Governments with quite a different "current" agrarian policy.

${ }^{13}$ About 2100 former cooperatives and other organizations formed on their bases; more than 1300 state farms and agrocompanies; a number of municipal and "mixed" firms.
} 
out in the best interests of legitimate beneficiaries (individuals, groups, or general public). Experience has shown that agrarian assets have not been properly managed (under or over used) and their value lost or artificially depreciated. Most of the efforts of Liquidation Councils and Privatization Boards have been directed to prolong transformation process (on job consumption of members, keeping power and rent taking), and to arrange unfair assets (income) transfer to a particular interest group.

\section{Domination of provisional forms for land supply}

Many agents have got recognized their private rights on farmland but until recently only few of them had their land completely restituted. Most of claimants have got restored their rights only in "ideal borders" ("on papers") and they have been able to acquire land for temporally (for one season) use. Consequently for a very long period only provisional modes for organization of land supply transactions have been possible such as internal integration in own farming or short lease (direct contract or through mediation of Land Commissions).

Lack of full ownership has affected significantly development and structure of land transactions, character and stability of farm organizations, and efficiency of land use. Sell and long-lease markets for agricultural land have not emerged until recently. Ownership cooperation in a group farming or leasing on annual base have been only ways to extend farm size. "Ideal" character of titles has allowed large blocks of farmland to be governed in a consolidated manner by newly emerging cooperative and private structures. Unprecedented concentration in land management has been achieved for a short period and with relatively low costs for individuals ${ }^{14}$. Now about 3500 big private farms $(0.2 \%$ of all farms) and 2300 production cooperatives manage $76 \%$ of all cultivated land in the country, averaging 493 ha and 709 ha accordingly.

However, practicing of short lease on fragmented ownership and with a big number of suppliers has been associated with high transacting costs (for annual renegotiations with lessors, for land replacements), reluctance of longer-term land specific investments and deterioration of soil fertility, strong preference to one season crops and rising of crop rotation problems. Agrarian agents neither have been able to get actual return on their land rights on sell or (long) lease markets, nor to use their titles for effective governing of other transactions such as: using land as a share in legal entities and joint ventures, for interlinked organizations (e.g. land collateral against bank credit) etc. Part time farming and over cooperation at large scale have developed as substitute. Besides, most of newly formed larger agrofirms, partnerships, and production cooperatives (based mainly on provisional lease in contracts) have been in a regime of little sustainability.

\section{Renaissance of "producers" cooperatives}

There has been a "boom" in production cooperation during liquidation (and in post-liquidation stages) of old cooperative structures. By 1995 all existed in the beginning of transformation 2100 "collective farms" were liquidated and their assets were

${ }^{14}$ All contracted (by a private farmer or a cooperative) area for lease "in ideal borders" (often with a very big number of owners for small plots dispersed in many locations) is allocated in a consolidated plot (s) by respective Land Commission. 
distributed into "individual shares". During the same period new 2600 production cooperatives were set up and their number have grown up to 3200 later on.

Long term "cooperative tradition", pro-cooperative policy of a previous (socialist) Government, opportunities to explore economy of scale or scope (on technology, or pure transacting activities), some ideological (e.g. "red" or "blue" cooperatives) or ethnical ("turkish", "bulgarian", "macedonian" cooperatives) factors, all have been important for new cooperation phenomenon. However, in many instances, cooperative mode has been either a singe or the most effective form for farming organization. Around $60 \%$ of Bulgarian households have got some agricultural land and individual stakes in the assets of liquidated ancient cooperatives. Absence of settled rights on agrarian resources (farmland, disputed material assets), small size of acquired property ${ }^{15}$, and inherited structure of shares (high share of debt, large passive or indivisible assets ${ }^{16}$ ), have made adjustment through market transactions uneasy.

Firstly, market trade with land and other property has been difficult (high transaction costs) because of lack of full ownership titles and low demand from new developing structures. In supply side there have been enormous costs to find a reliable partner and to (re) negotiate lease season after season (moreover on fragmented lands and assets), low confidence in new emerging private farming, and great economic uncertainty (institutional and contractual instability, rapid inflation, high expectation about future value of agrarian land). Ownership form (own farming, partnership, cooperative) has happened to be the cheapest or the only possible mode for organization of transacting.

Secondly, many agrarian agents have found their individual assets in high bilateral or multilateral dependency (physical indivisibility into individual shares; site or capacity dependency). Condition of high human capital specificity has been experiencing by many agrarian agents who used to be specialized in particular farming production or activities (mechanization, irrigation, veterinary, accountancy) of previous collective farms. They have found their skills in high bilateral dependency with acquired physical assets and (or) in multilateral dependency with human capital of other agents (team work tradition, lack of management skills). Also in many cases owners have got restituted their land plots with fruit trees (vineyards etc) on them, and they could practically execute much operation (e.g. mechanization, plant protection, irrigation etc.) in a cooperation. In some cases physical distribution of a particular asset (key machinery, storage or processing facilities) could have put prospective farmers in unilateral dependency from a particular supplier or buyer (monopoly situation, losing employment opportunities, moving assets to another place or user). In order to make transactions possible or to overcome serious transaction difficulties in post liquidating stage, new agents have decided to keep (govern) dependant assets as a joint ownership.

Finally, most of the eligible land owners and shareholders have happened to live away from rural areas, or to have other business, or to be old of age, or to have no skills or

\footnotetext{
${ }^{15}$ Averaging of 2.7 ha of farmland (often splitted in many locations) per a landowner, and less than $\$ 100$ per an asset shareholder.

${ }^{16}$ Big machinery, buildings, processing and irrigation facilities etc. originally designed for a large-scale "public (collective) organization".
} 
capital to start own farms. Therefore, new owners have had no any alternative but liquidate (through sales, consumption, abandoning) ${ }^{17}$ or to govern transactions supported by interdependent assets through a cooperative mode. In that way more than $40 \%$ of the new owners have pulled (part or all of) their land and other assets in new production cooperatives. However, majority of "shareholders" has not been practically involved in cooperatives business or management ("separation of ownership from management"). Therefore, most of these organizations have been in fact either provisional sharecropping (unsustainable lease in) agreements or a particular type of large agri-corporations.

Existing production cooperatives do not have effective mechanisms for safeguarding interests of members. There is a high asymmetry in competency and available information of managers and outside owners. For instance, cooperative managers possess detailed information for technological potential, yield and income levels, available resources etc, but they are not always interested to disclose it (because of desire to show "progress" in annual reporting or to use cooperative property for private goals). . On the other hand, cooperative members are interested to get full internal information for optimal decision making. However, their individual costs are extremely high because of lack of competency, "hidden" or misleading information, need to prove others correctness of observed or suspected mismanagement etc. Besides, individual gain from possible improvement of organization is a small portion of total benefit which is eventually distributed between all members of coalition (passive and active). Consequently there are no strong incentives for individual efforts for amelioration of common welfare ("free riding" problem). Therefore, it is impossible an effective control on cooperative activities individually, through a numerous General Assembly or incompetent Management Board (members of which could be easily interlinked or otherwise bribed by Executive in order to keep them "agreeable" or "silent").

Besides, there is no "alternative market" for a great part of cooperative assets ("member oriented organization"). There is no danger for "failure" or "take over" by a competitor which could discipline managers (self-financed by members "non for profit organization"). "Unique" character makes it impossible to use "market" criteria for evaluation of much of cooperative activities (oriented to specific needs of "own members"), and any achieved results could be presented as "efficient" by management. All these give great opportunities for inefficient and incompetent management, and for using coops in the best interests of managers or some groups around them (on job consumption, unprofitable for members deals, corruption). In fact majority of all production cooperatives has rarely shown a good economic performance.

Moreover, there has been a growing conflict between working and non working members of cooperatives as former want an increase in current income (salaries, income in kind, other benefits) and later are interested in higher capital payments (land rent, dividends). Besides, there are differences in investment preferences of younger and

${ }^{17}$ Physical liquidation has been an "unexpected" result of economic liquidation (distribution) of agrarian assets. For instance prereform number of cows has decreased by $45 \%$, pigs with $64 \%$, sheeps and goats with $68 \%$, and poultry by $65 \%$. Also a large part of farm building, equipment, irrigation etc has been entirely destroyed. 
older working members. While old generation prefers higher current income and consumption (and lower long-term investments), youngers are interested in growth of long term efficiency and income through new capital investments.

Collective (democratic) decision making is associated with high transaction costs for reaching consensus as a result of big number of members (averaging 239 per a coop), low information or competence of a great part of them, conflict of interests of various contingencies, "votes trading", etc. Besides, "majority rule" is not always in direction with efficiency since votes are not proportional to interests according to invested capital. Most of cooperative members are with small shares and they benefit in larger extend from "equal" use of cooperative assets. As a result many (new) cooperatives have been practicing inefficient mechanisms from the past such as: "equal" remuneration, overemployment, redistribution from "profitable" to unprofitable activities, system of personal plots, adverse feeling towards private farming, keeping "social stability", authoritarian management etc. All these restrict stimulus for large individual investments in specific cooperative (human, tangible, intellectual) capital and limit growth in efficiency (and size) of organization.

Lastly, internal integration of transactions in such "large scale" leads to increase in internal costs for coordination, stimulation, accounting, and monitoring ("problems of team production"). This requires development of complex (often hierarchical) and expensive structures for internal management (departments, divisions, units), and large investments for their design, experimentation, reorganization. However, cooperative governance not always is associated with technological or other (e.g. transacting) benefits comparing to alternative forms for farm organization, which would require such an internalization of transactions ${ }^{18}$. Besides, relative "small" size of individual production cooperatives makes them ineffective for governance of some types of transactions which need a large scale (nationwide) "cooperation" (e.g. for accumulation of credit resources, effective protection from a monopoly etc.)

\section{New life for small self-sufficient farming}

Traditional prereform system of "personal plots" 19 has found a new life in a small-scale natural farming. Now nine out of ten private farms are smaller than 1 hectare and in general case self-sufficient farms ${ }^{20}$. More than a half of all farms have an average size of 0.09 hectare and more resemble gardens than real farms. Most of livestock farms are also miniature "domestic farms"21.

In a situation of high underemployment and unemployment ${ }^{22}$, and a large share of food budget (40-50\% of total household expenses), "part-time" farming has turned to be a source for significant income for every other household. High market transacting costs

\footnotetext{
${ }^{18}$ For instance, organization of a similar (production) activity in small groups or individual farms would often be with lower comparative costs for formation, maintenance, and development.

${ }^{19}$ In 1989 there were 1.6 million "personal farms" averaging 0.38 ha

"There are more than 1.5 million farms smaller than 1 ha with an average size of 0.21 ha

More than $80 \%$ of livestock farms have 1 cow and $15 \%$ only two cows; $64 \%$ of farms bread one pig and $22 \%$ are with two pigs; more than $88 \%$ of sheep farms have less than 10 sheeps; and more than $80 \%$ raise less than 15 pouitry

${ }^{22}$ Real level of unemployment is higher than official figure of $16 \%$.
} 
("missing markets" for land and credit, lack of ownership titles, high contract enforcement costs) and low labor opportunity costs (no employment alternatives, inappropriate qualification or age) have forced many agrarian agents to integrate available "free" resources (labor, land, livestock, "farming knowledge") in own natural farm. There have been many "new comers" to agriculture (unemployed or low paid white or blue colors workers ${ }^{23}$ ). For them farming has been the last resort (or buffer) during high institutional instability (process of privatization and introduction of new governing mechanisms) and fundamental restructuring of economy (markets adjustment, reorganization, rapid inflation, high redundancy, strong necessity for prequalification, expectation for future opportunities in other businesses). In a number of cases self-sufficient farming has developed as a substitute for uncertain (in term of quality, origin, availability) or unsafe (e.g. residual chemicals, mad-cow decease etc) outside food supply. Besides, farming as main or related activity has been traditionally a favorite spare time occupation (hobby) for a good part of population.

Self-consistent "farms" are with a low productivity since no investments in specialized capital (labor, know-how, industrial materials etc) have been made. Primitive (backward) technologies dominate and performance has been rare according to modern human health, environmental, and animal welfare standards. There have been no incentives for investments in farm-specific assets (training, specialization of labor, modern machinery) and for extension of farm size since: limited scale of household consumption, higher alternative (current or long-term) return on personal resources ${ }^{24}$, or noneconomic reasons (family prestige, social status). Intensity of transactions has been weak since there are no transactions at all (one-person natural farm) or low costs internal transactions (between farnily members) and (or) rare barter or market exchanges are carried out.

In some instances self-sufficient farming has got a character of collective (family, group, communal) farm (e.g. common grazing of animal, collective use of pastures or water supply etc). Such an extension of operations has given an opportunity to increase efficiency (explore economy on scale for some activities), for mutual assistance (partial cooperation or specialization of labor), or labor substitution (possibility to keep a farm along with another main activity). However, high transacting costs for coordination and mutual control (on over or misuse of resources, labor shrinking etc) have limited this form to family borders, close friendships, or neighborhoods.

\section{Development of business farms}

Commercial private farms are with various size and types. Most of these farms are governed according to the "rules of competition" since they rely heavily on market (input supply, marketing etc) transactions. Therefore, business farms tend to improve technology, management, and efficiency. Some farms extend farm operations into marketing, small processing, and service supply etc. In many instances commercial farms apply more complex governance modes for transacting with vertical partners such as: long term

\footnotetext{
${ }^{23}$ University professors, teachers, researchers, medical staff, military and government officers etc.

${ }^{24}$ For instance, a surgeon-farmer or a lawyer-farmer invest in specific health-care or law human capital, and "free cash" keep in commercial banks
} 
contracts, product specifications, interlinked organization (e.g. credit supply against marketing) etc. Usually boundaries of business farms have grown around specific entrepreneurial capital of a manager (e.g. technological skills; managerial experience; ability to supervise hired labor, and to govern outside transactions). However, high costs for outside (market) supply of agrarian credit (for long term investment, working capital) and for marketing of output have often restricted operational size beyond technologically optimal level.

Small farms (less than 2 hectare) rely mainly on family resources (labor, land, capital). They are specialized in labor intensive productions (e.g. horticulture, fruits, tobacco, grapes, tobacco, aetheteric plants), or in a small scale livestock-crop production. Middle size (between 2-10 hectare) and large (bigger than 10ha) farms are in cereal and some industrial (e.g. sunflower) crops, or in mix livestock-crop operations. Most of them lease in land and employ workers extensively. Adjustment process has been associated with a reduction in number of all farms and a shift of land management toward largest farm $\mathrm{s}^{25}$. In many cases larger farms have been set up by managers and specialists of ancient public farms. They have used their accumulated experience (managerial, technological etc), personal and business ties, prereform preferential positions, to concentrate specialized material assets and to develop large farm operations (inside and outside transactions under a single management).

Not rare bigger farms represent small partnerships or group farming between friends or (and) relatives. This form gives individual farmers an opportunity to pull resources, and to explore economy of scale and scope; to increase internal specialization of labor (in management, complex technological operations) and to improve efficiency; to have better inputs and capital supply, and marketing positions etc. Besides, very often partners possess farm-specific and complementary to each-others capital (management skills, know-how, technological knowledge, business ties, accumulated cash etc) which increase benefits from internal organization (cooperation). Family or fiends partnership has been particularly efficient in conditions of high economic and behavioral uncertainty, big incentives for opportunism and low confidence between partners, not working public system for contract enforcement etc. In order to avoid opportunism of specialized nonfamily labor special forms giving rights on residual output (income share) have been used (in fact turning them in a co-owner). Also various modes for interlinked organization of transactions are practiced (providing a job along with "free" housing, food, land, services, protection) as risk to lose those additional (nonmarket) benefits restrict opportunistic behavior of nonfamily labor.

In many instances greater and large farms are formally registered agrofirms or partnerships. Preferences of status of a legal entity have been determined by diversification into farm related (trade, agrotourism, processing, restaurant) or independent activities. Besides, this form gives a number of extra advantages such as: opportunity to develop a firm specific capital (e.g. brand names, reputation, public confidence) and its exploitation (extension into daughters companies), trade (sells, licensing, franchising), intergeneration transfer (inheriting); explicit rights for taking part in particular types of transactions (e.g. privatization actions, government and international assistance

\footnotetext{
${ }^{25}$ Between 1993-96 number of large farms dropped 5 times while their average size increased 3.5 folds.
} 
programs); for overcoming existing institutional restrictions (for direct foreign investments on land, for maximum size of owned or leased farmland, for engaging in cereal trading) etc.

Number of various registered agrarian organizations with private ownership has risen 8 folds since 1990. They are mainly in capital intensive productions (such as pig, poultry, greenhouse, grain, and horticulture, seeds and seedlings), or in agrarian services (mechanization, plant protection etc.). Most of agrifirms are with "private ownership of local physical person" ( $97 \%$ of total number). Mode of a sole (family, small group) management and ownership give a great incentive and coordinating advantages (single owner of all "residual" rights, low internal transacting costs). It also allows exploring economy on most (noncomplex) of agrarian technologies, and reaching optimal operational size in firm's boundaries.

Part of agrifirms have been set up after privatization of state agro companies as large partnerships of former employees. Great number of them has been experiencing serious economic problems because of inherited assets dependency (low technology level, large share of over-depreciated assets, big depth, inefficient managerial and incentive structure) and incompetent (or corrupted) management. Some of state companies have been taken over by other organizations (groups) and in fact represent joint ventures with participation of large outside (agrarian or nonagrarian) capital. This integration has increased potential of efficiency through exploring existing business ties, marketing channels, and investment capacity. However, in some cases such an external control over management has been associated with profit outflows (through transfer pricing and otherwise) and worsening of economic position of daughter companies.

\section{Market modes}

There has been boom in intensity of market transactions since 1990 when practically all markets were liberalized. Agrarian agents have started to carry out their transactions through various market and contractual modes (direct marketing, different forms of terminal and wholesales trade, risk taking deals etc). Big variety of market forms have been developed ranging from traditional farmers markets through natural exchanges (barter) and long term commitments, to future trades. Also a significant adjustment of integral forms (size and types of transactions within farms, firms, and cooperatives; and value of assets of various farms ${ }^{26}$ ) through market transacting has been in place.

However, most of agents have had no experience in using market (bidding, contracting etc) for their inputs supply and marketing. Transaction costs associated with first transaction of agents have been very great (because of high uncertainty and risk, low competence and confidence between partners, high expectation for profitable deals in future) and restricted scale of free market modes. Besides, many agrarian agents can not stand market pressure (price, quality and quantity competition, with local and international participants alike) and they have got to cease transactions or integrate them

\footnotetext{
${ }^{26}$ In new economic conditions some of inherited agrarian assets have got a high market value (e.g. vineyards, greenhouses, processing capacity) while others have little (large equipment for public farming) or no value (e.g. at-farm airports mainly used for visits of the former Communist leader, "show rooms", sport facilities etc).
} 
in a small scale (production for own consumption, interlinked).

Development of agrarian markets (emergence, adjustments) has been slower than expected ("missing markets", high price variations between different markets and regions, great price fluctuations etc). That has been a result of high structural instability (fast changing business environment and regulations), long-term absence of macroconomic stability (sky high levels of inflation), unspecified property rights on main agrarian resources (land, environmental resources, intellectual property), and delay in restructuring (privatization, demonopolization, reorganization) of ancient organizations. Besides, there have not been built a modern market infrastructure (such as systems of wholesale markets, for market information, and for quality standards), and an effective system for Law and contract enforcement. Individual market transaction costs (for searching "good" prices and reliable partners, for negotiations and contracting, for protection from unwanted exchange, for dispute resolutions etc) have been extremely high. Moreover, incentives for opportunistic behavior in high information asymmetry and uncertainty (easy cheating during contracting and contract execution), low frequency of transactions between partners ("reputation does not matter"), significant costs for contract enforcement ("no danger for punishment"), economic hardships ("survival" consideration), wishes to become rich faster ${ }^{27}$, have been very high. Many otherwise effective market transactions have been blocked (e.g. credit and extension supply, entire agrarian risk market etc) or failed to occur in an effective scale ("there is uncultivated land in one place, and unused labor or machinery in another place").

Besides, domination of primitive forms have come to existence such as direct marketing, street trade, cash and carry deals, fly by night trades, clientalization, and reliance on personal (instead of faceless market) relationships at national or even international scales. Also many transactions have been carried out through more complicated (and "expensive") forms such overcontracting, interlinked organization, widespread use of economic hostages to secure credible commitment, exclusive preference to a singe mode ("leases" for land and other fixed assets; "sales" for mobile assets; "short-term contracts" for hired labor) etc.

Widespread unwanted "market" exchanges have also taken place. Monopoly positions of state or newly privatized processing companies continue to originate serious problems for small farmers in inputs supply (high rent, requirements for supply of non demanded "complementary" products etc) and marketing (unfavorable pricing, delay payments, compensation of farmers with processed products instead of cash etc). Also many farmers have experienced cheating by "fly by nights traders" which take farm output without fulfilling contracted obligations thereafter, or supply fake inputs (chemicals, machinery etc) ${ }^{28}$. Besides, special (criminal) "security firms" have appeared wishing to "protect" farm property and crop for a large premium (unwanted sharing). Lastly, little appropriability as a result of unspecified or unenforced rights on most of

\footnotetext{
${ }^{2 \tau}$ In first years of transition "take hot money and run away" was often a basic principle rather than an exemption in business relationships. Special organizations were deliberately created to make a "big strike" (fake banks, financial pyramids, "phantom" wholesale firms etc)

${ }^{28}$ Trade with fake (non corresponding to origin and quality) or unregistered (uncertified for tax or other purposes) products for final consumption has been a big economic problem since 1989 now.
} 
agricultural land, intellectual agrarian products, environmental resources (e.g. clean air, water etc.) have made difficult transacting across open markets.

Very often official (public, municipality, mixed) markets have been "too expensive" for agrarian agents because of big distance or small trade volume, high registration fees and commissions, uncomfortable and time-taking regulations (e.g. working hours, obligatory requirements for quality certificates), complicated paper works, necessity to bribe market personnel (in order "to get" a better deal, storage facilities, information etc). Instead informal markets modes have been broadly used as substitute such as: terminal, wholesales, retail; services for contract enforcement ("wrestlers", insurance companies); inputs supply etc. Besides, a great "gray" and even illegal markets (sector) have been formed in order to avoid tax, license, duties etc payments or to overcome existing legal restrictions (such as ban on import or export of some farm products; production and trade with cannabis etc)

In conditions of underdeveloped markets and high uncertainty (natural for agriculture, economic, behavioral, institutional) most of investments in agrarian area have been in a regime of strong specificity ("buried in land"). Individuals transactions (and assets) have happened to depend form each other rather than from all others (free market). In order to overcome transactional risk and to protect dependent investments from different forms of uncertainty mix rather then pure market modes have been broadly applied. Various economic groups, alliances, cooperation agreements, interlinked modes (for instance credit, inputs, and extension supply against marketing) have been formed which now govern a significant part of all agrarian transactions. Another organizational reaction of agrarian agents has been investments in less specific capital (one-season crops, "mobile" assets on wheels, bank deposits in hard currency etc). Productivity in agrarian sphere has dropped significantly since 1989 as a consequence of lower level of specialized long-term investments.

In order to facilitate market transactions in high uncertainty special private forms have started to emerge (such as giving guarantees, internal quality control by food chain, testing period before employment, leasing sells, consumer cooperatives etc). Also investments in specific transacting capital have been made (e.g. good name, reputation, trade and brand names, origins, advertisements etc) which would be lost in case of opportunistic behavior. Besides, specialized costs saving modes for repeated transactions have appeared (e.g. membership trade, consignation trade, collective input supply and marketing, mini-wholesales etc). Lastly, different quasi (contractual) or entirely integrated (on base of ownership) forms have been used to govern transactions with high mutual dependency (time of delivery, product specification, capacity dependency, "nish" markets).

\section{Emergence of farmers organizations}

Development of farmer organizations of western type has not been easy and it is far from complete. Large number of new agrarian agents, their little "organizational" experience (in association, institutional modernization, lobbying), unclarified or conflicted interests of individual agents (as land owners, farmers, hired labors, consumers, taxpayers), and high transacting costs for "organizational development" (for initiating, legal registration, building, training, overcoming free riding), all have slowed down organi- 
zational modernization. Initiating "form above" agrarian organizations have not attracted many farmers because of their "political" (limited) character, big number, short life, uncertainty for opportunism (using for exclusive benefits of a particular person or groups) and free riding.

However, in a number of cases high potential of transacting benefits from "collective actions" has been effectively explored. Successful farm organizations have appeared when "common interests" of agrarian agents (and benefits from collective mode of transacting) have been clear and costs of organizing have been relatively low. That has been either in highly specialized homogenous productions (tobacco, grain etc) concentrated in particular regions of the country or in highly concentrated industries (e.g. pig, poultry) where small number of big players dominate.

Missing market situation has been one of the reasons for emergence of a collective mode for transacting. Markets for long-term credit supply, agrarian risk, mechanization services etc have been typical examples when joint ownership forms have been built as substitute (e.g. credit associations, risk sharing and service supply cooperatives). Besides, in many instances farmers have been experiencing serious transacting difficulties (such as local or national monopoly, high uncertainty, strong unilateral dependency) and they have developed internal governance modes (e.g. bargaining associations, joint processing companies, input supply and marketing cooperatives). Moreover, often there has been a great potential to save on transaction costs (because of high frequency, economy of scale and scope) through a collective organization of particular transacting (e.g. collective price negotiation, input supply or marketing). Also when there has been high (inherited or newly formed) interdependency of assets of various agrarian agents (farmers, processors, input and capital suppliers, researchers) special private forms have developed to facilitate transacting (e.g. cooperation or joint ownership in processing, regional associations for innovation etc).

More often various agrarian agents have evolved special organizations for expressing economic interests, and lobbying for public good supply and government interventions (e.g. branch associations, special producers and interests groups). In a number of instances their efforts have been successful and public interventions in their interests have been achieved (for instance price guaranties for tobacco and cereals, subsidized credit for grain production etc). Besides, significant institutional modernization has been in place and some organizations have got a special public (power) status (to represent farmers, to initiate and participate in agrarian legislation etc) and exclusive rights (to control quality or certify origins of particular products, to carry out breeding and water supply transactions etc).

\section{Trilateral modes}

In transitional conditions a large part of agrarian transactions could not have been effectively governed by free market or pure private modes. These transaction have been in a regime of high uncertainty and assets specificity, low recurrence and appropriability. Various forms of a third party involvement in individual transacting (e.g. assistance, mediation, regulation, support etc) have taken place to make them more efficient or possible at all.

Much of the efforts of governmental, local authorities, international agencies, non for 
profit organizations etc, have been to assist market and private transactions of agrarian agents. Providing "free" agro-market information (for land, agrarian inputs, farm outputs); setting up and controlling product standards (quality, origin, residual chemicals); regulation of working conditions (minimal wages, labor safety, working hours); extension education; assistance in farmers organization; licensing of veterinarian and various laboratories; giving quality certificate (for experts or producers); testing of new varieties, machinery, and chemicals; all have been examples in this respect.

Next direction has been a third party support (e.g. institutional, financial, know-how) of some types of private transactions. Development of a system of wholesales markets, formation of farm-credit associations, various lines for financing of agrarian and related activities (farming, processing, marketing, agroturism), programs for recovering of traditional industries (livestock, wine, rose oil), all have been examples for such mixed (hybrid) modes of organizations.

Finally, there have been public (in house) organization and provision as only possible mode for carrying out some kinds of agrarian transactions. Agricultural research and advisory system; infrastructural development; veterinarian and sanitary control; hail prevention; meteorological forecast; educational and special purpose (e.g. for cure of drug addicted person) farms; storage and deactivation of useless chemicals of former Agro-industrial complexes (inherited unilateral dependency), all have been examples for such governance mode.

In some cases public interventions in agrarian transactions have been a result of political wishes (of governments, agrarian bureaucrats) to introduce western type market and private structures, and to accelerate farming transformation. Most of existing specialized public structures have been reorganized (e.g. agrarian research, all services in the structure of Ministry of Agriculture) and new governing mechanisms have been introduced (for priority setting, management, funding, public control etc). Besides, many new public organizations have been set up in order to meet new demand for public involvement in agrarian transactions (e.g. National Agricultural Advisory System, Fund "Agriculture" etc).

In other instances public involvement has been a consequence of priorities of international donor agencies (for institutional building, transfer of modern technologies and know-how, sustainable development of rural areas etc). Foreign assistance has been a result of: government weakness ("failure") to mobilize internal (national) resources, lack of capacity or experience to carry particular transactions. Different complex multilateral forms for effective governance (for priority setting, execution, control) have developed which involve international partners, national or local authorities, and private counterparts.

Not rare, public involvement has been induced by organized efforts (successful lobbying) in interests of one or another group (e.g. large farmers, producers or business groups, final consumers, government or local nomenclatures). Consequently many trilateral modes have been introduced which not always govern transactions in the most effective for all participant and society way. For instance, instead of more (costs and incentives) effective forms of public involvement (assistance, regulation, hybrid) pure public and hierarchical organizations have been mostly preferred (e.g. State System of Agrarian Extension, State Companies for Irrigation, State System for Agro-market Information etc). Besides, significant deformation of transacting structures has come up 
from imposing a mandatory mode (expensive trilateral governance) or from ultimate "private response" to bad public intervention". In such cases most of the efforts of interested agents have been directed to keep (or improve) forms guaranteeing them better transacting positions ("public rent") instead of improving mutual benefits of all participants.

Lastly, significant private transacting costs have been involved to participate in trilateral public modes (e.g. large national or EU programs). Number of specialized forms (local, international, and mixed; private, hybrid, informal) have developed: to gain such projects (preparation for tenders, lobbying, bribing officials), to manage projects (govern relationships with donors, subcontracting of project execution), and to carry them out (set up teams of experts, cooperation or internal organization).

\section{PROSPECTS FOR ORGANIZATIONAL MODERNIZATION}

\section{Driving factors for institutional development}

There are two groups of factors, which will determine institutional structure for agrarian transacting in years to come.

Firstly, that will be the political commitment to modernize agriculture according to the European Union standards (adaptation of agrarian legislation, Common Agricultural Policy; building parallel administrative and market structures; introduction of product quality, food safety, labor use, animal welfare, and environmental standards, etc). There will be also outside pressure (EU and other international institutions) to pursue institutional transformation during accession negotiations ${ }^{30}$. Besides, various assistance and structural support programs (e.g. PHARE, SAPARD etc) will direct agrarian and rural development toward European priorities. However, for overall economic performance is not only important to introduce "modern" formal institutions (e.g. to translate and adapt European Union Directives) but they must be properly enforced. Otherwise "imported" legislation would not work as expected in the specific environment of local (formal and informal) institutions.

There is an enormous potential for saving on transacting costs, and for intensifying market and private transactions, through Government intervention (for decreasing uncertainty and assets specificity, increasing appropriability and recurrence of transactions). It is in proper assignment and protection of various property rights (on land, labor, safe food and clean environment, intellectual property etc) though improvement of public (absolute and contract rights) enforcement system (court, arbitrage etc). Next, that is in further liberalization of markets, relaxing trade regime (bureaucratic obstacles, licensing), and enforcing fear exchange (restructuring of monopoly, fighting against gray and black structures, etc). Finally, it is in assisting of market and private transactions

\footnotetext{
${ }^{29}$ For instance, applying for and getting public subsidies (e.g. preferential working credit) even when they are not really needed (e.g. large farmers); inappropriate use of acquired public credits (e.g. outside agriculture); illegal export or decreased production as a result of export ban or complicated trade regime etc.

${ }^{30}$ Bulgaria is an associate member of the European Union since 1993. Formal negotiations for full membership started in the beginning of 2000 and according to the official schedule they will be completed by the end of 1996 .
} 
through: setting up quality standards, providing price information, extension education, preferential agrarian credit, mediation of land transactions, land consolidation programs, development of agrarian infrastructure (wholesale markets, storage and processing facilities, irrigation, roads, telecommunication), assisting in farmers association etc.

In conditions of high food costs in all household expenditures and tight budget restrictions, possibility to mobilize political resources for expensive agrarian programs will continue to be very limited. Therefore, total adjustment costs of agrarian development would be hardly paid by general taxpayers. Thus less expensive Government involvement through institutional support and hybrid forms instead of large spending programs and in-house production will likely prevail. Besides, it is very important to design effective governance structures for trilateral modes which will facilitate coordination, let adjustments, restrict opportunism, and contain mechanisms for a permanent public control. Transitional experience has been associated with significant direct costs and negative impacts $^{31}$, great duplication of activity and little flexibility of public (including international) agencies, and enormous abuse of public power at all levels (individual corruption of low paid public servants, "organized uses" by economic or criminal groups etc).

Secondly, coordination and incentive power of market competition will be a significant force for organizational development both in respect of intensification (pressure) at local markets and as high export potential ${ }^{32}$. It will lead to gradual adjustment of size of agrarian organizations and modernization of forms of farming. There will be growing individual initiatives to improve institutional (formal and informal) framework of their transacting. Agrarian agents will extend (innovate, experiment, adjust, develop) variety of market and private institutions of governance in order to use benefits of transacting (and save on costs, overcome difficulties, intensify exchange, face competition) including with foreign partners as well. Besides, various interests in agrarian development would be gradually clarified, and efficiency of (lobbying, pressure) organization for inducement of public (Government, international) support will be improved. Therefore, there should be removed any institutional restrictions for individuals to use market and to arrange own private modes for transacting according to their special needs and specific attributes of each transaction (e.g. degree of mutual or unilateral dependency, assets specificity, uncertainty, and appropriability). Otherwise negative tendency for emerging of inefficient forms for transacting as substitutes would continue. Moreover agrarian agents association should be encouraged (and assisted), and mechanisms for representation of different interest groups (land owners, farmers, hired labor, agroindustry, final consumers) in public decision making are to be introduced.

\section{Horizontal and vertical boundaries of farm}

Individual costs for outside transacting will gradually decrease along with development of agrarian markets, quality standards, contract enforcement system, public

${ }^{31}$ There have been a lot of examples for bad Government interventions in agrarian transactions after 1989: "liquidation" of old structures, implementation of land restitution and privatization of state assests, restructuring of agrarian research, price controls, export bans etc.

${ }^{32}$ National prices for main agrarian products are still lower than international (e.g. European) levels: for wheat with $14 \%$, corn- $35 \%$, sunflower $-25 \%$, milk $-41 \%$, butter $-54 \%$, beef meat $-37 \%$, pig meat $-19 \%$ etc. 
support for agriculture etc. Then benefits from exchange (trade) of owned resources and from specialization (exploitation of technological opportunities for economy of scale and scope, renting on specific capital etc) will increase. It will become much more efficient to organize transactions across market (e.g. instead of own cultivation leasing out of land and selling of specialized labor) or to extend farm size through investments in internally organized specialized capital (management, technological knowledge, modern machinery, intrafarm division and specialization of labor). Besides, farmers ability to govern effectively more internal and outside transactions will increase along with improvement of managerial ("learning by doing", entrepreneurship) experience, standardization of agrarian technologies and products, opportunities to form or use farmers organizations, development of free extension education etc. Accordingly, incentives for internal organization ("overintegration") at small scale will disappear in the future. Number of self-sufficient and small farms will gradually decrease, and there will be a further transfer (concentration) of management of agrarian resources to bigger and professional farms.

Most of agrarian technologies and products (inputs, outputs) are characterized with little complexity and low dynamics. Besides, potential of economy of scale and scope from general agrarian technology is not big and could be easily achieved if some institutional restrictions do not exist (e.g. for maximal size of land ownership or lease in). However, natural uncertainty in agriculture is usually high, and efficiency is strongly dependent from quality and time of performance of critical operations (e.g. cultivation, water supply, treating with chemicals, input of fertilizers, protection and harvesting of yields, marketing). That is why very often managerial and technological knowledge could be highly farm specific. Permanent governance and monitoring of hired labor in a large area, and for measurement of work (or contracted) results is either very expensive or impossible (because of bounded rationality). Therefore, extension of farm size is heavily restricted from availability of specialized family (low costs) labor for core farm operations, and opportunity to use effective outside inputs and service supply contracts for nonspecific to the farm transactions (e.g. output based compensation of labor, share tenancy for land supply, buying instead of on-farm producing of inputs etc).

In general cases optimal specialization (cooperation) in management and in major farming operations can be easily realized in boundaries of a family (or one-person) farm without any need for further horizontal integration (with competitors producing same products). Family farm would be extremely efficient in transitional conditions of high economic and behavioral uncertainty (high possibility for opportunism), not working contract enforcement system, and less complicated agrarian technologies. It is also an effective inexpensive form for preservation and (intergeneration) transfer of specific intrafirm capital (specialized knowledge and skills for technologies and products, learning by doing experience, building a reputation etc).

However, family resources (land, capital, labor, technological skills) for exploring potential of economy on scale ("one product") or scope ("two or more related products") are usually limited. In a number of instances high transaction costs will restrict (or block) farm extension through outside (market) contracts for inputs and credit supply, marketing etc. For example, high transitional uncertainty makes outside procurement of financial resources either very costly (high interest rate, restriction for use of credit, 
requirements for collateral blocking resource mobility etc) or impissible. Besides, after final settlment of ownership rights (introduction into "real borders") land supply in large farms (besed mainly on provisional lease in contracts) will become more expensive and would shift down their size $e^{33}$. Moreover, private costs for protection of absolute rights (on agrarian property) from unwanted exchange would also be high ${ }^{34}$.

Various partnership modes (such as group farming, producers cooperatives, agro-companies) will be used to overcome outside restriction for farm extension and for development of "internal division" of labor (in management and technological functions). In most instances different partners will own complementary farm specific assets (land, managerial skills, technological knowledge, business connections, accumulated cash etc) which would add to benefits form internal organization. However, farm enlargement through nonfamily partners is associated with increase in internal transaction costs for horizontal coordination, reaching a consensus, for conflict resolutions, for avoiding possible opportunism ("team working" problems) etc which limits effective members of a coalition (internal specialization). Hence horizontal cooperation will be restricted by potential to explore economy on specific (interdependent) for farm assets. Any further integration of transactions would be associated with new internal costs without any additional benefits. Such horizontal extension of farm would be efficient in homogenous, and less labor intensive production (e.g. cereals, sunflower) where decision making and control of opportunism do not require significant costs.

Besides, special organization with competitors will develop for joint exploration of existing potential for economy of scale (and scope) on transacting costs, or in order to overcome possible transaction difficulties (e.g. risk form market price fluctuation, strong assets dependency, monopoly, low appropriability, missing markets etc). However, there would be strong incentives to set up (or participate in) inputs supply or marketing cooperatives; cartels for price negotiation; risk sharing associations; joint processing; organizations for innovation, lobbying and alike, only if individuals organizational costs (for development, maintenance, avoiding free riding etc) are low comparing to receiving individual transacting benefits.

When assets specificity will be relatively high to a particular transaction in vertical chain (strong unilateral or mutual dependency with a particular supplier or buyer) and behavioral uncertainty is high, then a special private form would be designed to safeguard dependent transactions. It would be an internal integration if economy on specific assets could be reached within a farm (e.g. dairy cows and milking facilities; greenhouse building and specialized equipment). Otherwise, a joint ownership outside farm gates (shareholding, cooperation in processing or storage facilities), or tight modes for quasi (stakeholding alliances, supply and delivery arrangements, interlinked contracts, economic hostages) or entire vertical integration with upstream or downstream partners

\footnotetext{
" In order to keep (extend) farm size big operators either have to buy large lands or to negotiate a new kind of land organization with a very great number of "real" owners for small plots allocated in various locations. In both cases their transaction and production costs would grow up and economic performance worsen.

${ }^{34}$ Our survey shows that high costs for yield protection from stealing has been a main factor restricting extension of larger farms in Bulgaria.
} 
would govern transactions (e.g. poultry and swan production, cattle feeding etc). Vertical integration at farm level will depend on possibility to reach economy of scale (scope) for more than one specialized activity (diversification of farming, developing of marketing and processing operations etc) and faces limits of managerial diseconomy. Otherwise, agrarian agents would build inefficient facilities and lose on production costs competition (price of outside procurement); or invest in specialized assets but lose on governance costs (management of more than one specialized activities, needs to buy from or sell to competitors). Moreover, when assets dependency is negligible integration into related stages would incur only additional costs without any extra benefits ${ }^{35}$.

Large part of agrarian inputs, technologies, and outputs will increasingly have "mass" (standardized) character. Therefore, market (rather than vertically integrated) transactions at farm gates will dominate. However, there will be a parallel tendency toward specialization into productions for "nish markets" and products with a special quality (e.g. "chemical free" vegetables, meat with "low fat and cholesterol levels", grape with "controlled sugar" content for special wines, "strong wheat" for spaghetti etc). They will require investments with increasing or high specificity to a particular (or group of) buyer, and "integrated" (join) management of transactions in farming, processing industries, food chains, through specification of production technologies, products quantity and quality, time of harvesting and delivery etc. Such transactions can hardly be governed by traditional markets for standardized farm outputs and they would bring to a life special private forms for vertical integration of transactions (such as narrow specialized wholesale markets with few traders, long term contracts specification, internal integration within a company).

\section{Modernization of agrarian cooperatives}

There will be a significant modernization in management and ownership structures of much of existing cooperatives. One part of production cooperatives will reorganize their activities toward carrying transactions, which can not be integrated in individual farms ("small size") and market organization is not efficient (because of big uncertainty, high specificity of assets, unilateral dependency). Those will be mainly vertical and highly specific to small farms transactions associated with: overcoming market uncertainty, sharing risk of price fluctuation, saving on inputs supply and marketing costs, service supply to members, economy on scale and scope of specialized capital or production activities etc.

That will be strongly members-oriented non for profit organization, since it would govern highly specific for members capital (oriented to meet members own demand). Such a mode will have big advantages to alternative organizations such as small operational costs, not profit making, economy on scale and scope, and power to face outside monopoly. Only an internal form based on (joint) ownership can govern and safeguard effectively highly specific (dependent) transactions. However, these transactions could not be carried in individual farms since potential of economy on specific assets can not be realized (small transacting scale). That is why cooperation (join ownership) with some of competitors (other individual farms) would be efficient or only possible mode for

\footnotetext{
${ }^{35}$ Low transaction specific investment's risk is more effectively managed not through diversification of production (vertical integration) but at capital market through extending assets portfolio.
} 
organization of transactions in common interests (outside individual farm gates) ${ }^{36}$. In some instances cooperation would be to economize on "pure" transaction activities (such as inputs supply, wholesale and retail trade, cartel for price negotiation, political lobbying). In other instances, cooperative would integrate transactions with "productive" character (e.g. production activity or services for members; storage, processing, transport of individual farm's output).

This organization would not be "profit making" since there is no interest to profit from "yourself" through transactions (selling-buying products and services) between two organizations with same owner. Besides, cooperative form has some legal advantages for minimization of certain transaction costs. In some cases this mode would be preferred since it allows economy from tax (local, central) payments on intrafarm activities. In other instances cooperation would be the single (legally possible) form for organization of some transactions (e.g. accumulation of credit resources in agriculture, access to preferential governmental programs, overcoming restrictions for nationwide integration of transactions ${ }^{3 i}$ ).

Therefore, member oriented cooperatives will be an alternative to private farming in some (less labor intensive) production and in agricultural services. However, number of existing complex production cooperatives will significantly decrease because of self-liquidation of some of them, amalgamation (merger) or specialization (into services) of others. There will be a differentiation of types of cooperatives and size adjustment according to specific needs of members and character of carried activities (innovation, savings, input supply etc). Besides, various intercooperative and mixed (with private, corporate or public forms) forms would emerge for effective organization of particular transactions (to intensify mutual exchange, strengthen local or export positions, gain economy on large operations, facilitate transactions with high dependency, perform social functions in rural areas, lobby for public goods supply). Development of cooperative structures will be associated with bigger farmer-member involvement in their management, and extension of public control on their activities.

Another part of existing cooperatives is market oriented and in fact competes with individual farms. Most of these cooperatives will likely be transferred to agrofirms and manage as close corporation. Agrocompany will integrate intrafirm specific capital and its borders would be determined by scale of transactions supported by such assets. It will have market orientation and outgoing products (and services) will have universal but not specific to a farm (which require cooperation for services) or for corporation itself (requiring intermal vertical integration) character.

Corporation would be an effective form for capital intensive farm operations with an "industrial" character (e.g. greenhouse, poultry, swan). Such productions require concentration of investments in highly specialized assets and necessity to integrate "shares" of many owners. Besides, there is a big standardization of operations and productivity in

\footnotetext{
${ }^{36}$ For instance, "collective" production of feed for "private" livestock, "common organization" for water supply for private farms etc.

${ }^{3 i}$ For instance, there are opportunities for association (cooperation) of cooperatives and nationwide organization (integration, control) of transactions (inter-cooperative ventures, cartel for price formation, credit association etc), which are illegal for other business forms (restriction under the Competition Law for a "maximum market share").
} 
these industries ("module" greenhouses, "module" poultry or pig farms etc). Market orientation of organization makes it "easy" for outside shareholders to evaluate efficiency of management through "synthetic indicators" such as operational profit, rate of profitability, capitalization, dividends level and the like. Therefore, it would be possible to carry out an effective control over managers of corporation through an elected by owners Management Board. Competition also will discipline (self-control) managers since there would be a risk for bankruptcy or take-over (by a competitor) in case of inefficient management. Manager's opportunism could be additionally restricted by introduction of special governance mechanisms practiced by other businesses (such as dependence of salary level from operational efficiency, receiving part of compensation in form of company shares etc).

Internal transaction costs would be much lower and incentives for investments in specific capital much higher in a labor owned firms (same owners of personal and other forms of specific corporate capital). This form would be particularly efficient in intensive but low crowded productions where individual contribution is easily measured and mutual control against opportunism effective ("self-enforced" labor contract). In some cases cooperative form would be applied in labor owned farm because of tax advantages, opportunities for outside association of transactions etc. Besides, in conditions of high economic instability (big uncertainty, low employment alternatives) non for profit organization would be preferred by working owners. Unlike other business forms cooperative mode guarantees employment and social security payments despite lower levels of return on invested capital (e.g. lower wages, lower than market or absence of rent and dividend payments).

Agriculture rarely requires complex technologies and large investments in specific material or intangible assets (e.g. patents, know-now, trade names etc). Besides, "conflicted" interests, different possibility for opportunism, and unequal ability for effective (mutual) control on behavioral uncertainty of participating agrarian agents (hired labor, managers, outside owners of nonpersonal capital etc), all increase enormously costs for internal organization. That is why less suitable for farming would be complex hierarchical organizations from corporate type associated with strong specialization in internal management (close corporation) or even functional division of management from ownership (open corporation).

\section{Potential for public intervention in agrarian transactions}

In transitional agriculture there have been a lot of "failures" of market and private sector to carry transactions with little appropriability, high uncertainty and assets specificity, and low frequency. There has been a tendency to "correct". these failures by setting up various types in-house public organizations (Water Supply and Plant Protection Companies, Systems for Agro-market Information and Hail Protection, Agriculture Advisory and Veterinary Services, etc).

In a public agrofirm there are no agents with strong personal interests in long term efficiency (development) since neither outside (appointed from "above") members of

\footnotetext{
${ }^{38}$ In a public firm owner of nonlabor capital is the State, Local authority, or another community (e.g. foundation, international assistance program etc)
} 
Managerial Board nor Executive Manager or working team have residual rights on firm's capital $^{38}$. In general case there is no competitive market for output of public firm ("natural selection" and danger from bankruptcy) ${ }^{39}$ which could discipline management. Therefore, criteria for evaluation of performance and for extension of firm size ("scale of funding") are determined "administratively" (from higher authority level). Usually only firm's manager possesses full information for effective organization (funding requirements, directions for improvement of productivity etc). However, he has little incentives to reveal it to supervisors or public since it would show weakness in activity, induce pressure for amelioration of efficiency (intensification of efforts, budget cuts), create "social problems" (reorganization and redundancy) etc. Responsible officials have no adequate information (and incentives) and very often estimates on budget and performance are based on "suggestions" from firm management (which is strongly interested to overestimate current results and funding requirements). Besides, few "key" figures (with competency and power in Ministry, Municipality, Supervisory Board) could be easily "bribed" with some form of personal benefits (interlinked transactions, transfer payments etc). In principle "achievement" of good funding and high evaluation, and "precise" meeting administrative formalities, take a significant part of management efforts in a public firm. That is why such a mode is more "oriented upward" toward formal requirements (orders) of agrarian bureaucracy rather than to real customers (owners of agrarian resources, farmers, final consumers) and their actual needs.

Various mechanisms for decentralization (partial or full "self-financing", "managerial autonomy" etc) and delegation of "rights on residual product" to the manager (and working team) could be used to increase incentives for amelioration of efficiency (intensification of efforts, economy on expenditures, taking entrepreneurial risk, internal "self-control" on opportunism etc). However, such rights of "self-management" are usually restricted (because of the public character of the firm) in respect to: scope of activity, price range (in case of monopoly or oligopoly position), distribution of income (between investment-salary), freedom to use (sell or lease out) long-term assets, profit making, etc. Public control is to be carried out by special mechanisms (supervisory boards, system of auditing, detailed specifications of activity, regulation of staff number and prices levels etc) and hierarchical (intrafirm and outside) structures for accountancy and control. All these restrict local initiatives and increase overall governance costs (at firm and upper hierarchical levels). Besides, personal rights on firms assets are temporal and non transferable ${ }^{40}$ which direct individual efforts toward maximization of current "production" consumption (misuse of materials and working time) or over "accumulation" in labor capital (through training, education, business trips etc). "Quasi" self-management rights often only give additional opportunities to use public assets for personal or group (s) interests: to provide good jobs for central and regional agrarian nomenclature; to accommodate relatives and friends; to subsidize own private business (through transfer pricing, using cheap or free equipment, stealing working time) etc.

\footnotetext{
${ }^{3}$ Public forms come to existence namely because of "missing market" or "failure" of market or private sector to organize transactions with a social importance.

${ }^{40}$ Individual's rights on public firm's residuals (income, assets) are lost in time of quitting job, retirement, dismissal or reorganization
} 
Lastly, reorganization or liquidation of public firms is very difficult since that is not in best interests of competent individuals (local managers, working teams, "dependent" upper bureaucracy) ${ }^{41}$. Outside low costs control (legislative, administrative, public, media) over firm is impossible and therefore it is very difficult to induce such a modernization (strong opposition, information asymmetry, free riding). Normally it takes a lot of time and social costs for initiating and proving necessity of such public actions, and for associated with it debating, arranging political "compromises", introducing new regulations, taking into accounts "social" consequences etc.

Public firm is not an effective form for organization of agrarian transactions and is to be used as a last resort. Often it is possible to apply more efficient mode for public involvement in agrarian transacting (e.g. assistance, regulation, funding). Instead of state or municipality firm (farm) it would be more efficient to contract activity ("public order") to a private or non for profit organization. State can assist financially or even own long-term assets, but management to be carried by a professional (e.g. farmer, research) organization or a private company. Private management or farmers self-management will improve efficiency of trilateral organization since it would increase individual incentives of participants and decrease public governing costs (for setting up, maintenance, and control of public firms). Public interests in such hybrid modes will be safeguarded by: priority setting for public spending, specification of activity, outside auditing, direct involvement in "internal" management bodies by interested public agents, publication of annual reports, public participation with shares in the mix organization etc. Besides, a third party (government) investments in assets with a high specificity and low appropriability is a prerequisite, which would further induce private investments in more "mobile" and universal assets ${ }^{42}$ of hybrid organization.

In some instances, private firm (or consortium) would be an effective form for organization of trilateral transactions (e.g. veterinary services, supply of agro-market information, management of development projects etc). Private organization is more flexible and works according efficiency principle ("rules of competition" for wining public projects). There are strong incentives for improvement of efficiency and for private investments in specific assets (specialization) since they will increase comparative advantages and chances to win new bids after contract completion (and time for a renewal of contract comes). Besides, periodic system of (re) contracting is an "attestation of efficiency" and restricts firm's opportunistic behavior (strong interests in a long-term participation in public projects).

In other instances, delegation of management of trilateral transactions to a farm organization would be the most efficient. Firstly, this mode gives opportunity for taking into account of real farmers demands and the best ways to meet this demand (no information asymmetry). Secondly, farmers are strongly interested in amelioration of organization, and they have real mechanisms (self-management) to improve efficiency

${ }^{41}$ Such reorganization would bring only intensification of efforts, possible closure of job positions, need for prequalification, end of opportunity to get a "public rent" from firm etc.

4" For later assets there is alternative actual or second hand market which safeguards return on private capital (and stimulates private investment) even when joint venture is not successful and is to be broken down. 
and to control opportunism (single user of benefits). Thirdly, this form induces strong incentives for farmers coo-investments in specialized (managerial, organizational, tangible) capital (ownership on residual rights) and eventually leads to decrease in "social price" of transactions. Lastly, organization is cost effective since it does not have profit orientation (unlike private firm). Incentives for high efficiency of trilateral mode increase when farmers partly participate in funding of activity (e.g. parafiscal taxes for extension service, mandatory shares in credit association, user-fees for irrigation water etc). Such mixed quasipublic or quasiprivate forms would be very efficient for transactions requiring a large scale collective organization, with high assets specificity or unilateral dependency, big uncertainty, low appropriability and frequency (e.g. applied agrarian research, technological innovation, livestock breeding, extension supply, long-term crediting, water supply, management of resources in mountainous regions etc).

In third cases, a transfer of public functions to specialized non-for profit organization (e.g. agrarian university, research institute, professional association, independent laboratory or experts) would be the most effective way for trilateral governance (e.g. testing and evaluation of new varieties, chemicals and machinery; quality and origin control for farm products, etc).

In many instances instead of expensive trilateral modes it would be more efficient to apply less complicated forms of public involvements (assistance, mediation, regulation) in market and private transactions (e.g. setting quality standards, giving tax or credit preferences, assisting farmers association, direct support to private forms etc). Development of a new (special) organization is always associated with enormous (designing, development, maintenance, enforcement etc) costs and not rare benefits go away from targeted groups (e.g. for agrarian administration, for profiting of private firms close to the Government etc). Moreover, lack of private (market) "appropriability" of agrarian transactions is often a result of undefined (or clearly defined) agrarian property rights and inefficient system for their enforcement (Bachev and Tsuji). In this case the most effective Government intervention will be a modernization of institutional environment ("internalize externalities") through introduction of new private rights (e.g. exclusive monopoly rights on biological innovations, rights on "clean environment" and "safe food" etc) and an effective system for their enforcement (assignment, control, regulation, conflicts resolution).

\section{CONCLUSIONS}

Neoclassical scenario for transformation of previous agrarian model ("free market plus private ownership") has not worked in Bulgarian conditions. Transition has changed "rules of the game" but it has not made agrarian agents "more rational" and "less opportunistic". Consequently costs for new property rights and institutional development, and for market and private modes of individual transacting have taken a good part of all social expenditures.

Transaction costs economizing perspective gives us a new look at driving factors and prospects for institutional modernization of Bulgarian agriculture. High assets dependency, big uncertainty, low appropriability, and less frequency have determined a specific transitional structure of agrarian transacting. Less market transacting, big reliance on informal relationships at large scale, great extent of "over" integrated modes, part time 
farming and production cooperation phenomenon, block of all classes of transactions etc, all have come to existence. Besides, a large number of inefficient or contradictory third party (e.g. Government, NGO's, international assistance) involvements in agrarian transacting have been in place. All this has deformed substantially emerging farming system, and domination of primitive and "gray" structures, little sustainability of large business and cooperative farms, significant distortion of national agrarian capital, and backward technological "development", have come to agenda.

Low efficiency of public in-house organization and limited budget sources would restrict Government direct intervention in agrarian transactions. Agrarian policy should be toward exploring potential of market, private, and cooperative modes through new property rights provision, institutional and infrastructural support, improving law and contract enforcement, market information, extension education, assisting farmers association etc. Less expensive modes for trilateral governance (coordination, control on opportunism, incentives for specific investments) with active involvement of private sector and farmers organizations are to be preferred.

\section{REFERENCES}

Bachev, H. and Tsuji, M. 2001 "Governing of Agrarian Transactions" (under publication)

Bachev, H. 2000 "Bulgarian Experience in Transformation of Farm Structures", in Farm Management and Rural Planning, Kyushu University

Bachev, et all 2000 Revicw of Agricultural Policies in Bulgaria, OECD, Paris

Coase, R. 1937 "The Nature of the Firm", Economika, No 4

Furuboth, E. and Richter, R. 1998 "Institutions and Economic Theory. Contribution of the New Institutional Economics", The University of Michigan Press, Anu Arbor

North, D. 1990 "Institutions, Institutional Change, and Economic Performance, Cambridge University Press, Cambridge

Williamson, O. 1985 "The Economic Institutions of Capitalism", Free Press, New York 